\title{
Spatio-temporal variability of Gladiolus imbricatus L. populations in different plant communities near Kraków
}

\author{
Kinga Kostrakiewicz-Gieralt
}

\begin{abstract}
Department of Plant Ecology, Institute of Botany, Jagiellonian University, Lubicz 46, 31-512 Kraków, Poland, e-mail: kinga.kostrakiewicz@uj.edu.pl
\end{abstract}

Received: 19 October 2017 / Accepted: 30 October 2017

\begin{abstract}
The investigations, aimed to assess the abundance, stage structure and distribution of shoots, as well as the chosen traits of generative shoots (number of leaves and length of the longest one, height of shoot, length of inflorescence and the dorsal tepal of the lowermost flower, number of seed capsules) of Gladiolus imbricatus L. were conducted in the years 2015-2017. The observations were carried out from Kraków-Pychowice to Tyniec in abandoned moor-grass meadow (Patch I), shrub willows (Patch II), macroforb community (Patch III) and community dominated by tall-growing grasses (Patch IV). The population abundance augmented gradually in subsequent study sites. Additionally, the temporal fluctuations of shoot number were recorded in all the Patches. The similar in consecutive years' stage structure differs among the study sites. The occurrence of juvenile, vegetative and generative shoots in Patch I might suggest the successful seedling recruitment, while the lack of shoots in pregenerative stages in Patches II-IV might indicate the absence of safe sites for the appearance of new genets. The occurrence of clusters of shoots in Patches II-IV might be a consequence of clonal growth. The traits of generative shoots rather did not show the temporal variability, but they presented spatial variability and in most cases augmented from Patch I, via Patches II and III, to Patch IV.

The performed studies enabled ascertaining that the population occurring in Patch I presents the best condition despite the lowest abundance of shoots. Also the other, more abundant populations, inhabiting Patches II-IV might persist in the colonised sites thanks to the vegetative multiplication of ramets and maximisation of chances for successful pollination and effective seed dissemination.
\end{abstract}

Key words: Gladiolus imbricatus L. abundance, stage structure, spatial structure, clonal plant, rare species, ecobiology, population dynamics.

\section{Introduction}

The sword lily Gladiolus imbricatus L. is a clonal plant creating underground tubers performing the role of storage and regenerative organs of shoot origin (Klimešová \& Klimeš, 2006). However, according to Moora et al. (2007) the vegetative spread is limited, and production of more than one daughter corm within one season is rare, while reproduction from seeds is common. The aforementioned authors distinguished the following developmental stages: seedlings (individuals with cotyledon), juveniles (individuals forming a nonflowering shoot with one leaf), vegetative (individuals creating a nonflowering shoot with at least two leaves) and generative (individuals creating a flowering shoot). The adult generative individuals form 30-80 cm tall, leaved stalks, bearing one-sided inflorescence containing usually from several to a dozen or so purple flowers, blooming from June to July. The flowers are pollinated by insects from the order Hymenoptera. The fruit is a slightly inflated capsule containing numerous wind-dispersed seeds.

The area of distribution of Gladiolus imbricatus L. covers Central and Eastern Europe, the Mediterranean, Caucasia and West Siberia (Hultén \& Fries, 1986). In Poland, it abundantly occurs in the southern highlands and lower mountains, whereas in the other regions it is rather rare 
(Zając \& Zając, 2001). The populations of Gladiolus imbricatus L. occur in termophilous oak forests Potentillo albae-Quercetum, humid lowland meadows from the Molinion alliance, oats and barley fields, as well as phytocenoses dominated by Calamagrostis epigejos and Carex brizoides.

Gladiolus imbricatus L. is included into numerous national Red Lists of Vascular Plants (Lilleleht, 1998; Holub \& Proházka, 2000; Moser et al., 2002; Andrušaitis, 2003; Király, 2007). It is also enlisted in the Polish Red List of Vascular Plants (Kaźmierczakowa et al., 2016) in the category 'near threatened', as well as in many regional 'Red Lists or Books' (e.g. Jakubowska-Gabara \& Kucharski, 1999; Głowacki et al., 2003; Markowski \& Buliński, 2004; Jackowiak et al., 2007; Bróż, Przemyski, 2009; Kołodziejek, 2011; Babczyńska-Sendek et al., 2012; Cwener et al., 2016). Moreover, according to Rozporządzenie (2014) it belongs to strictly protected species.

The hitherto investigations concerning the sword lily individuals and populations have focused on the natural hybridisation between Gladiolus imbricatus and G. palustris (Szczepaniak et al., 2016), in vitro technologies for micropropagation, multiplication, corm development, somatic embryogenesis and medium-term storage culture (Rakosy-Tican et al., 2012), the influence of management on condition of populations (Moora et al., 2007), the effect of gaps in continuous plant cover and litter on seedling recruitment (Jõgar \& Moora, 2008; Kostrakiewicz-Gierałt, 2014a) and the abundance and structure of populations in Molinion caeruleae meadows (Kubikova \& Zeidler, 2011; Kostrakiewicz-Gierałt, 2014b).

Despite the gradual growth in the number of studies carried out in populations of Gladiolus imbricatus in the last decades, the current state of knowledge is still insufficient and further investigations are still required. Therefore the variability of sword lily populations in different phytocenoses was investigated. The detailed aims concentrated on the assessment of: (i) the abundance of shoots, (ii) the age structure and distribution of shoots, and (iii) the chosen traits of generative shoots (i.e. the number of leaves and length of the longest of them, height of stems and inflorescences, number and length of flowers, as well as number of capsules).

\section{Study area}

The investigations were carried out in the southern part of Poland from Kraków-Pychowice to Tyniec, south of the Vistula River. The research area is at ca. $210 \mathrm{~m}$ a.s.1, on a low flood terrace of the Vistula, 3-6 $\mathrm{m}$ high. The water table is $0-2 \mathrm{~m}$ below the ground surface. Formerly, in the aforementioned area, patches of Molinion caeruleae prevailed (Zarzycki, 1958), but long-time lack of manage- ment promoted the development of macroforb communities, Phragmites swamps and willow brushwood (Dubiel, 1991, 1996). Other plant communities also occur in the vicinity, such as deciduous forests, xerothermic calcareous grasslands and ruderal communities.

The study area consisted of four study Patches differentiated by species composition and habitat conditions: (1) Patch I measuring ca. $800 \mathrm{~m}^{2}$ represented moor-grass meadow characterised by the presence of rosette-form species with erect or procumbent stems and delicate underground organs, e.g. Centaurea jacea, Lychnis flos-cuculi and Succisa pratensis; (2) Patch II covering an area ca. $900 \mathrm{~m}^{2}$ represented willow thicket dominated by Salix rosmarinifolia; (3) Patch III reaching ca. $600 \mathrm{~m}^{2}$ was established in a macroforb community prevailed by Filipendula ulmaria, Lythrum salicaria and Valeriana officinalis; and (4) Patch IV achieving approximately $600 \mathrm{~m}^{2}$ represented by phytocenose of tall-growing grasses such as Molinia caerulea and Deschampsia caespitosa.

\section{Material and methods}

\subsection{Field study}

In all of the above-mentioned patches, the survey of habitat conditions was performed on 15 July 2015. The cover of cryptogams, herbaceous plant, as well as shrubs and trees were visually estimated. In order to obtain the random samples in each plot, 20 throws with an iron ring, 30 $\mathrm{cm}$ in diameter, were made. Each time, one stem occurring in the centre of the ring was measured using a folding tape measure. Simultaneously, soil humidity in the centre of the ring was measured using a BIOWIN soil moisture sensor (range 1-10). The gradual increase of height of plant cover and soil moisture in consecutive patches are given in Table 1.

In 2015, in each of the aforementioned patches, all the shoots of Gladiolus imbricatus were inventoried. Subsequently, within each patch the one representative, permanent study plot $(10 \mathrm{~m} \times 10 \mathrm{~m})$ was set and fenced. Then, all the shoots growing within the study plots were counted and tagged with plastic pegs for further observations, carried out in the years 2013-2015. Each year the shoots were inventoried and assigned to a developmental stage according to Moora et al. (2007). Also, the distribution of shoots in the study plots was surveyed. Moreover, the following parameters were measured for all the labeled, generative shoots: (1) the number and leaves and the length of the longest leaf blade, (2) the height of the generative shoot from ground level to the tip, (3) the length of inflorescence from the lowermost to the uppermost flower, (4) the length of the dorsal tepal of the lowest flower, and (5) the number of capsules. 
Table 1 . The characteristics of study patches

\begin{tabular}{|c|c|c|c|c|}
\hline & Patch I & Patch II & Patch III & Patch IV \\
\hline Area $\left(m^{2}\right)$ & 800 & 900 & 600 & 600 \\
\hline Habitat & Moor-grass meadow & Willow brushwood & $\begin{array}{l}\text { Macroforb } \\
\text { community }\end{array}$ & Tall-grass community \\
\hline $\begin{array}{l}\text { Dominants } \\
\text { (species with cover } \\
\text { exceeding } 20 \% \text { ) }\end{array}$ & $\begin{array}{l}\text { Centaurea jacea, } \\
\text { Succisa pratensis, } \\
\text { Lychnis flos-cuculi }\end{array}$ & Salix rosmarinifolia & $\begin{array}{c}\text { Filipendula ulmaria, } \\
\text { Valeriana officinalis, } \\
\text { Lythrum salicaria }\end{array}$ & $\begin{array}{c}\text { Molinia caerulea } \\
\text { Deschampsia } \\
\text { caespitosa }\end{array}$ \\
\hline $\begin{array}{l}\text { Bryophyte cover } \\
(\%)\end{array}$ & 5 & 10 & 8 & 6 \\
\hline $\begin{array}{l}\text { Herbaceous plant } \\
\text { cover }(\%)\end{array}$ & 85 & 80 & 92 & 94 \\
\hline Shrub cover $(\%)$ & 0 & 10 & 0 & 0 \\
\hline $\begin{array}{l}\text { Mean (range) } \\
\text { height of standing } \\
\text { vegetation }(\mathrm{cm})\end{array}$ & $\begin{array}{c}44.6 \\
(13-92)\end{array}$ & $\begin{array}{c}45.2 \\
(21-78)\end{array}$ & $\begin{array}{c}68.9 \\
(29-124)\end{array}$ & $\begin{array}{c}79.2 \\
(38-145)\end{array}$ \\
\hline $\begin{array}{l}\text { Mean (range) soil } \\
\text { humidity (range: } \\
1-10 \text { ) }\end{array}$ & $\begin{array}{c}3.8 \\
(2-5)\end{array}$ & $\begin{array}{c}4.5 \\
(3-7)\end{array}$ & $\begin{array}{c}5.6 \\
(4-7)\end{array}$ & $\begin{array}{c}6.1 \\
(5-7)\end{array}$ \\
\hline
\end{tabular}

The length of leaves and height of the generative shoots were performed using a folding tape measure, while measurements of length of inflorescences, flowers and capsules were performed with a digital caliper. The investigations of shoot height, as well as traits of leaves, inflorescences and flowers, were conducted during the last week of July. The number of capsules was counted during the last week of August (the beginning of the seed release) to check the eventual number of capsules without seeds.

\subsection{Statistical analysis}

Chi-square statistics were used to test if there were significant temporal and spatial differences in the percentage of shoots representing diverse developmental stages. Subsequently, normal distribution of the untransformed data of the traits of generative shoots (number and length of leaves, height of shoots, length of inflorescences, length of the tepal of the lowermost flowers and number of capsules) in an individual sample (from a particular patch and year) was tested using the Kolmogorov-Smirnov test, while variance homogeneity was tested using the Levene test at the significance level of $p<0.05$. As the values of individual characteristics in some groups were not consistent with normal distribution, and the variance was not homogeneous, the non-parametric Kruskal-Wallis H test was used to check the significance of the differences of the aforementioned traits over consecutive years, as well as among successive Patches. All statistical analyses were performed using STATISTICA 10 software.

\section{Results}

The total abundance of Gladiolus imbricatus shoots achieved the lowest value in Patch I and the greatest value in Patch IV. A similar tendency was found in the permanent plots, where also the slight temporal changes of shoot numbers occurred (Table 2). The occurrence of juvenile, vegetative and generative shoots was found in Patch I, whereas only generative shoots appeared in the other Patches. Test $\chi^{2}$ confirmed the significant spatial differences and lack of temporal variability (Fig. 1). Within the study plot established in Patch I, the singular shoots of Gladiolus imbricatus were distributed randomly, while in the remaining study sites clusters of shoots were also observed (Fig. 2).

The traits of the generative stems rather did not present temporal variability, but they showed significant spatial variability. The number of leaves per shoot achieved the highest values in Patch IV, while the length of the longest leaf blade reached much greater values in Patches III and IV than in Patches I and II (Table 3). The height of shoot rose gradually in subsequent study sites, while the inflorescence length achieved the lowest values in Patch I and 

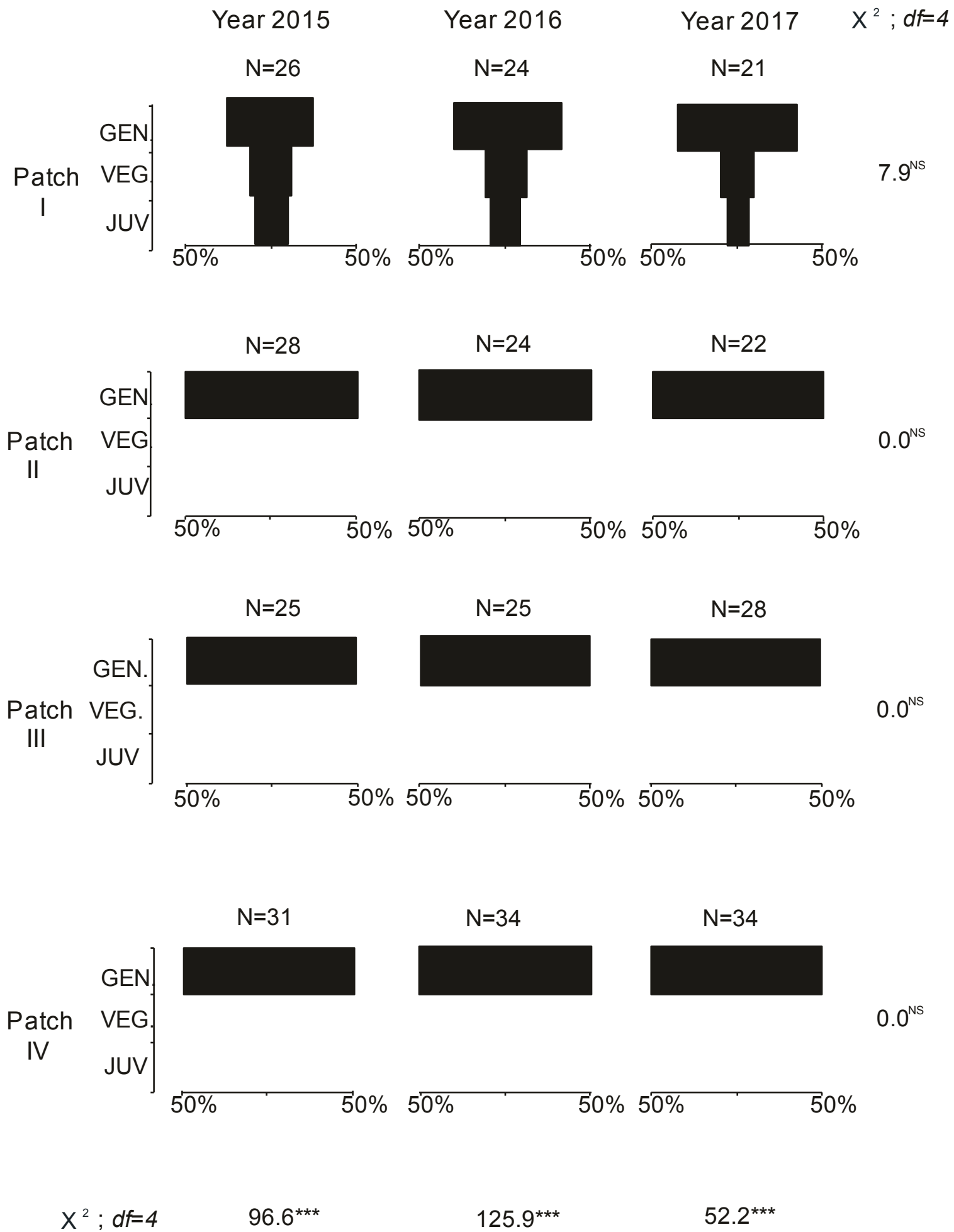

Figure 1. The structure of developmental stages of shoots of Gladiolus imbricatus L. in study plots established within studied moorgrass meadow (Patch I), willow brushwood (Patch II), macroforb community (Patch III) and tall-grass community (Patch IV) in the years 2015-2017. The symbols mean the level of statistical significance $\left(\chi^{2}\right.$ test): ${ }^{\text {NS }}$-not significant; ${ }_{-} \mathrm{P}<0.05$; $* *_{-} \mathrm{P}<0.01$; ***-P $<0.001$. Abbreviations; JUV- juvenile shoots, VEG- vegetative shoots, GEN- generative shoots. 
Year 2015
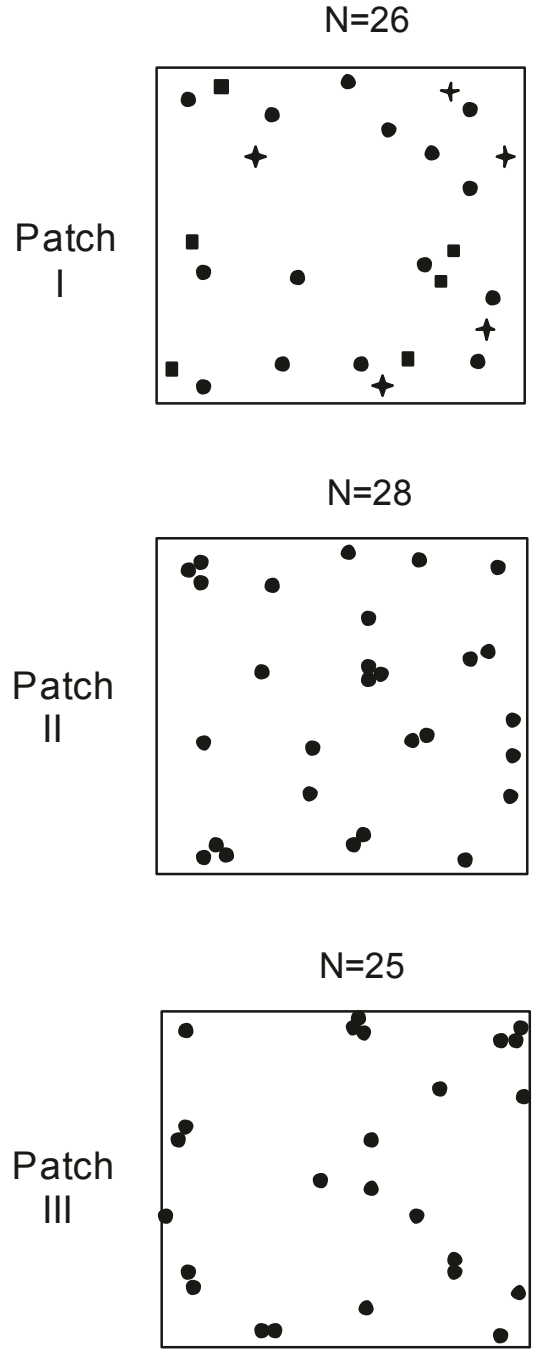

$N=31$

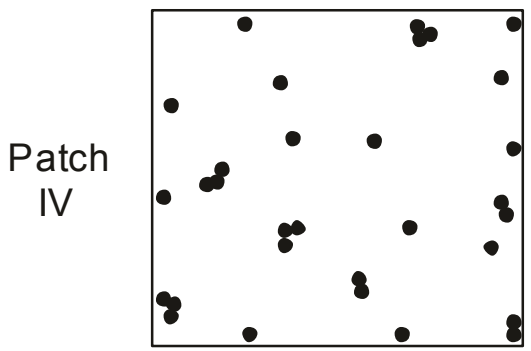

+ - juvenile shoots
Year 2016

$\mathrm{N}=24$

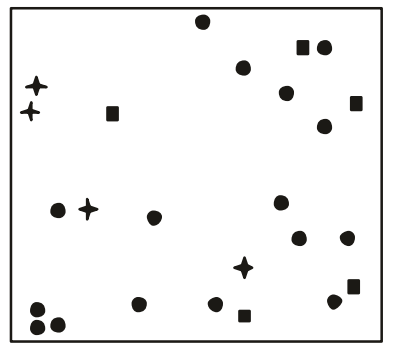

$\mathrm{N}=24$

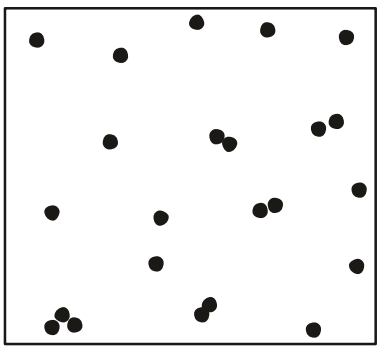

$\mathrm{N}=25$

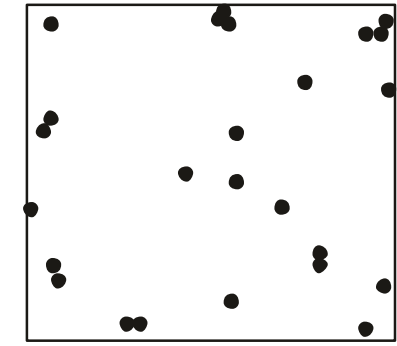

$\mathrm{N}=34$

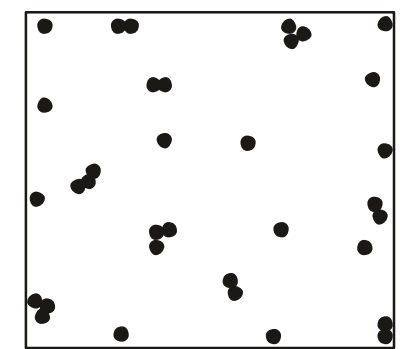

- - vegetative shoots
Year 2017

$\mathrm{N}=21$

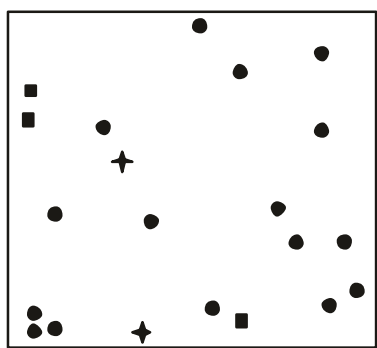

$\mathrm{N}=22$

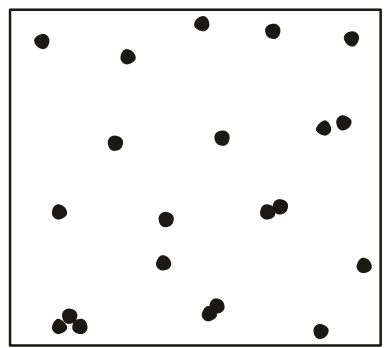

$\mathrm{N}=28$

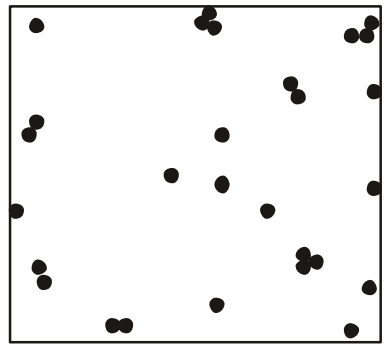

$\mathrm{N}=34$

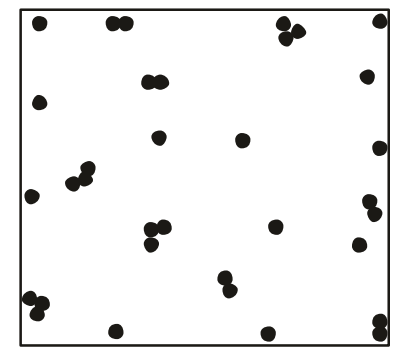

- - generativeshoots

Figure 2. The spatial distribution of juvenile, vegetative and generative shoots of Gladiolus imbricatus L. in study plots established within studied moor-grass meadow (Patch I), willow brushwood (Patch II), macroforb community (Patch III) and tall-grass community (Patch IV) in the years 2015-2017. Abbreviations: N-number of shoots. 
the highest ones in Patch IV. The length of the dorsal tepal of the lowermost flower reached the highest values in Patch IV (Table 4). In all the study sites all the capsules contained seeds. The number of fruits augmented gradually in subsequent study sites (Table 5).

\section{Discussion}

The performed observations showing that total number of shoots of Gladiolus imbricatus, rising in subsequent study sites and reaching from 157 to 197, is rather low. The much more abundant populations, reaching from about
600 to 250,000 individuals, were observed in meadows (Rombel-Bryzek, 2007; Mirek et al., 2014; Kołos, 2015; Ziaja \& Wójcik 2016), while the less abundant were found in forest communities (Piórek \& Krechowski, 2009; Gorzelak, 2012), as well as in phytocoenoses dominated by Calamagrostis epigejos (Falkowski, 2002) or Carex brizoides (Falkowski, 2002).

The temporal changes of the number of Gladiolus imbricatus shoots observed in all the study sites are an effect of dominance of factors contributing to a decrease or increase of the number of individuals. The decrease of shoot number might be an effect of individual mortality or physical damage of the aboveground parts of indi-

Table 2. The abundance of shoots of Gladiolus imbricatus L. in studied moor-grass meadow (patch I), willow brushwood (patch II), macroforb community (patch III) and tall-grass community (patch IV) in the years 2015-2017

\begin{tabular}{|l|c|c|c|c|c|}
\hline \multicolumn{2}{|l|}{} & Patch I & Patch II & Patch III & Patch IV \\
\hline $\begin{array}{l}\text { Total number of shoots } \\
\text { per Patch }\end{array}$ & 157 & 143 & 169 & 197 \\
\hline Number of shoots per & 2015 & 26 & 28 & 25 & 31 \\
study plot in the year & 2016 & 24 & 24 & 25 & 34 \\
& 2017 & 21 & 22 & 28 & 34 \\
\hline
\end{tabular}

Table 3. Number of leaves and the length $(\mathrm{cm})$ of the leaf blade of the longest one in generative shoots of Gladiolus imbricatus L. occurring in study plots established within studied moor-grass meadow (Patch I), willow brushwood (Patch II), macroforb community (Patch III) and tall-grass community (Patch IV) in the years 2015-2017. The symbols mean the level of statistical significance: ${ }^{\text {ns }}$-not significant; ${ }^{*}$ - $\mathrm{P}<0.05$; **- $\mathrm{P}<0.01$; ***-P $<0.001$

\begin{tabular}{|c|c|c|c|c|c|c|}
\hline & Year & Patch I & Patch II & Patch III & Patch IV & $\begin{array}{l}\text { The value of the } \\
\text { Kruskal-Wallis } H \text { test }\end{array}$ \\
\hline \multirow{3}{*}{$\begin{array}{l}\text { Mean number (range) } \\
\text { of leaves in the year }\end{array}$} & 2015 & $\begin{array}{c}2.7 \\
(2-4)\end{array}$ & $\begin{array}{c}2.8 \\
(2-4)\end{array}$ & $\begin{array}{c}2.9 \\
(2-4)\end{array}$ & $\begin{array}{c}3.2 \\
(2-4)\end{array}$ & $2.2^{\mathrm{ns}}$ \\
\hline & 2016 & $\begin{array}{c}3.0 \\
(2-4)\end{array}$ & $\begin{array}{c}2.9 \\
(2-4)\end{array}$ & $\begin{array}{c}2.8 \\
(2-4)\end{array}$ & $\begin{array}{c}3.3 \\
(2-4)\end{array}$ & $17.8^{* * *}$ \\
\hline & 2017 & $\begin{array}{c}2.9 \\
(2-4) \\
\end{array}$ & $\begin{array}{c}3.5 \\
(3-4) \\
\end{array}$ & $\begin{array}{c}3.5 \\
(2-4) \\
\end{array}$ & $\begin{array}{c}3.6 \\
(2-4) \\
\end{array}$ & $12.8^{* *}$ \\
\hline \multicolumn{2}{|l|}{$\begin{array}{l}\text { The value of the } \\
\text { Kruskal-Wallis test }\end{array}$} & $1.3^{\mathrm{ns}}$ & $7.6^{*}$ & $5.9^{\mathrm{ns}}$ & $7.4^{*}$ & \\
\hline \multirow{3}{*}{$\begin{array}{l}\text { Mean length (range) } \\
\text { of the longest leaf blade } \\
\text { in the year }\end{array}$} & 2015 & $\begin{array}{c}38.5 \\
(30-51)\end{array}$ & $\begin{array}{c}41.3 \\
(25-48)\end{array}$ & $\begin{array}{c}47.1 \\
(29-67)\end{array}$ & $\begin{array}{c}47.4 \\
(29-68)\end{array}$ & $25.0 * * *$ \\
\hline & 2016 & $\begin{array}{c}40.8 \\
(28-51)\end{array}$ & $\begin{array}{c}36.7 \\
(25-52)\end{array}$ & $\begin{array}{c}47.8 \\
(30-68)\end{array}$ & $\begin{array}{c}48.6 \\
(27-72)\end{array}$ & $23.0 * * *$ \\
\hline & 2017 & $\begin{array}{c}41.3 \\
(35-51)\end{array}$ & $\begin{array}{c}39.0 \\
(26-52)\end{array}$ & $\begin{array}{c}51.0 \\
(32-71)\end{array}$ & $\begin{array}{c}49.7 \\
(30-72)\end{array}$ & $28.4^{* * *}$ \\
\hline \multicolumn{2}{|l|}{$\begin{array}{l}\text { The value of the } \\
\text { Kruskal-Wallis test }\end{array}$} & $2.0^{\mathrm{ns}}$ & $1.5^{\mathrm{ns}}$ & $1.3^{\mathrm{ns}}$ & $1.7^{\mathrm{ns}}$ & \\
\hline
\end{tabular}


Table 4. Height of generative shoots $(\mathrm{cm})$, length of inflorescences $(\mathrm{cm})$ and the dorsal tepal of the lowermost flower of Gladiolus imbricatus L. occurring in study plots established within studied moor-grass meadow (Patch I), willow brushwood (Patch II), macroforb community (Patch III) and tall-grass community (Patch IV) in the years 2015-2017. The symbols mean the level of statistical significance: ${ }^{\text {ns }}$-not significant; ${ }^{*}-\mathrm{P}<0.05 ; * *-\mathrm{P}<0.01 ; * * *-\mathrm{P}<0.001$

\begin{tabular}{|c|c|c|c|c|c|c|}
\hline & Year & Patch I & Patch II & Patch III & Patch IV & $\begin{array}{c}\text { The value of the } \\
\text { Kruskal-Wallis } \\
\text { H test }\end{array}$ \\
\hline \multirow{3}{*}{$\begin{array}{l}\text { Mean height (range) of generative } \\
\text { shoots in the year }\end{array}$} & 2015 & $\begin{array}{c}66.6 \\
(55-80)\end{array}$ & $\begin{array}{c}77.7 \\
(58-96)\end{array}$ & $\begin{array}{c}83.9 \\
(58-103)\end{array}$ & $\begin{array}{c}89.1 \\
(64-120)\end{array}$ & $25.8 * * *$ \\
\hline & 2016 & $\begin{array}{c}68.3 \\
(55-87)\end{array}$ & $\begin{array}{c}79.4 \\
(61-98)\end{array}$ & $\begin{array}{c}87.8 \\
(60-111)\end{array}$ & $\begin{array}{c}94.0 \\
(69-128)\end{array}$ & $31.5^{* * *}$ \\
\hline & 2017 & $\begin{array}{c}73.2 \\
(58-89)\end{array}$ & $\begin{array}{c}81.8 \\
(65-102)\end{array}$ & $\begin{array}{c}92.6 \\
(63-118)\end{array}$ & $\begin{array}{c}96.1 \\
(69-134)\end{array}$ & $28.9 * * *$ \\
\hline \multicolumn{2}{|l|}{$\begin{array}{l}\text { The value of } \\
\text { the Kruskal-Wallis test }\end{array}$} & $3.9^{\text {ns }}$ & $2.9^{\text {ns }}$ & $2.2^{\mathrm{ns}}$ & $5.2^{\mathrm{ns}}$ & \\
\hline \multirow{3}{*}{$\begin{array}{l}\text { Mean length (range) of the } \\
\text { inflorescence in the year }\end{array}$} & 2015 & $\begin{array}{c}6.0 \\
(4.5-8.6)\end{array}$ & $\begin{array}{c}8.3 \\
(5.9-13.2)\end{array}$ & $\begin{array}{c}7.0 \\
(1.9-12.5)\end{array}$ & $\begin{array}{c}9.4 \\
(6.0-13.6)\end{array}$ & $27.1 * * *$ \\
\hline & 2016 & $\begin{array}{c}6.1 \\
(4.8-8.5)\end{array}$ & $\begin{array}{c}7.2 \\
(5.9-15.5)\end{array}$ & $\begin{array}{c}7.2 \\
(1.9-12.5)\end{array}$ & $\begin{array}{c}10.0 \\
(5.4-17.0)\end{array}$ & $28.3^{* * *}$ \\
\hline & 2017 & $\begin{array}{c}6.3 \\
(4.5-9.0)\end{array}$ & $\begin{array}{c}7.2 \\
(5.9-15.5)\end{array}$ & $\begin{array}{c}8.3 \\
(2.5-19.0)\end{array}$ & $\begin{array}{c}10.2 \\
(6.0-17.0)\end{array}$ & $26.2 * * *$ \\
\hline \multicolumn{2}{|l|}{$\begin{array}{l}\text { The value of the } \\
\text { Kruskal-Wallis test }\end{array}$} & $1.1^{\mathrm{ns}}$ & $1.5^{\mathrm{ns}}$ & $2.4^{\mathrm{ns}}$ & $1.6^{\mathrm{ns}}$ & \\
\hline \multirow{3}{*}{$\begin{array}{l}\text { Mean length (range) of dorsal } \\
\text { tepal in the year }\end{array}$} & 2015 & $\begin{array}{c}2.2 \\
(1.6-2.7)\end{array}$ & $\begin{array}{c}2.5 \\
(2.0-3.1)\end{array}$ & $\begin{array}{c}2.5 \\
(1.4-2.9)\end{array}$ & $\begin{array}{c}2.6 \\
(2.0-3.0)\end{array}$ & $18.7 * * *$ \\
\hline & 2016 & $\begin{array}{c}2.3 \\
(1.7-2.9)\end{array}$ & $\begin{array}{c}2.6 \\
(2.3-3.1)\end{array}$ & $\begin{array}{c}2.4 \\
(1.6-2.9)\end{array}$ & $\begin{array}{c}2.7 \\
(2.0-3.8)\end{array}$ & $14.9 * *$ \\
\hline & 2017 & $\begin{array}{c}2.4 \\
(1.9-2.9)\end{array}$ & $\begin{array}{c}2.2 \\
(2.3-3.2)\end{array}$ & $\begin{array}{c}2.4 \\
(1.5-2.9)\end{array}$ & $\begin{array}{c}2.7 \\
(2.0-3.8)\end{array}$ & $11.9 * *$ \\
\hline $\begin{array}{l}\text { The value of the } \\
\text { Kruskal-Wallis test }\end{array}$ & & $5.2^{\mathrm{ns}}$ & $1.8^{\mathrm{ns}}$ & $1.4^{\mathrm{ns}}$ & $2.6^{\mathrm{ns}}$ & \\
\hline
\end{tabular}

viduals. The mortality of sword lily individuals might be caused by the natural processes of senescence, the diseases triggered by pathogens such as fungi, bacteria and viruses, as well as rodent activity (Cantor \& Tolety, 2011), while the damage to shoots might be an effect of grazing (Kose \& Moora, 2005). On the other hand, the increase of shoot number might be the result of recruitment of new individuals in generative or in vegetative ways. Additionally, it is worth mentioning that the fluctuations in the number of Gladiolus imbricatus shoots might be an effect of vegetative dormancy of mature individuals, which spend at least one year entirely below ground without the appearance of any aboveground organs. Such a phenomenon, oc- curring in response to resource depletion or environmental stress, enables avoidance of unfavorable habitat conditions. Such a phenomenon in individuals of Gladiolus imbricatus was already observed by Kubikova and Zeidler (2011 and literature cited here), who noticed that ca. $50 \%$ of individuals from the examined sword lily populations remained in dormancy for two years. It is worth mentioning that although the dormancy was observed among numerous herbaceous perennial plants, it was best documented in orchids (Reintal et al., 2010; Tałałaj, 2015 and literature cited here).

The occurrence of shoots in pregenerative stages only in Patch I suggest the successful seedling recruitment and 
Table 5. Number (range) of seed capsules in generative shoots of Gladiolus imbricatus L. in study plots established within studied moor-grass meadow (Patch I), willow brushwood (Patch II), macroforb community (Patch III) and tall-grass community (Patch IV) in the years 2015-2017. The symbols mean the level of statistical significance: ${ }^{\text {ss }}$-not significant; ${ }_{-}-\mathrm{P}<0.05$; $*_{\text {- }} \mathrm{P}<0.01 ; * *_{-} \mathrm{P}<0.001$

\begin{tabular}{|c|c|c|c|c|c|c|}
\hline & Year & Patch I & Patch II & Patch III & Patch IV & $\begin{array}{l}\text { The value } \\
\text { of the Kruskal- } \\
\text { Wallis H test }\end{array}$ \\
\hline \multirow{3}{*}{$\begin{array}{l}\text { Mean number (range) of seed } \\
\text { capsules in the year }\end{array}$} & 2015 & $\begin{array}{c}4.3 \\
(4-6)\end{array}$ & $\begin{array}{c}5.6 \\
(3-10)\end{array}$ & $\begin{array}{c}5.9 \\
(4-11)\end{array}$ & $\begin{array}{c}6.7 \\
(3-10)\end{array}$ & $27.8^{* * *}$ \\
\hline & 2016 & $\begin{array}{c}5.1 \\
(3-7)\end{array}$ & $\begin{array}{c}5.0 \\
(2-9)\end{array}$ & $\begin{array}{c}6.3 \\
(3-12)\end{array}$ & $\begin{array}{c}6.8 \\
(3-11)\end{array}$ & $15.4 * *$ \\
\hline & 2017 & $\begin{array}{c}4.3 \\
(3-7)\end{array}$ & $\begin{array}{c}5.2 \\
(2-9)\end{array}$ & $\begin{array}{c}5.7 \\
(3-12)\end{array}$ & $\begin{array}{c}6.1 \\
(3-10)\end{array}$ & $12.5^{* *}$ \\
\hline $\begin{array}{l}\text { The value of the } \\
\text { Kruskal-Wallis test }\end{array}$ & & $6.1^{\mathrm{ns}}$ & $2.1^{\mathrm{ns}}$ & $2.4^{\mathrm{ns}}$ & $2.6^{\mathrm{ns}}$ & \\
\hline
\end{tabular}

their subsequent growth and development. According to Clothier (2003), germination of Gladiolus imbricatus occurs during cool, moist spring conditions, following periods of warm then cold stratification. The previous investigations showed that the spontaneous seedling recruitment occurs in gaps in the continuous plant canopy and litter layer (Kostrakiewicz-Gierałt, 2014a), originating as a result of human or animal activities. Additionally, the sowing experiments proved that seed germination might also occur in mowing patches (Jõgar \& Moora, 2008). The advantageous role of openings in the continuous plant cover and litter for the presence of individuals in early ontogenic stages was also observed in other bulbous geophyte inhabiting moist meadows of the Molinietalia order - Colchicum autumnale (Mróz, 2006).

The occurrence of clusters of generative shoots in Patches II, III and IV presumably indicate the successful clonal growth contributing to the multiplication of ramets and the production of descendants with the potential to become independent of the mother organism. The previous observations showed the clonal growth in Gladiolus cultivars (Rameau \& Gouyon, 1991) and its great enhancement after the clipping of leaves and inflorescences (Memon et al., 2009) or the adding of fertiliser (Ali et al., 2014; Saeed et al., 2014; Khattab et al., 2016). Successful clonal growth was also observed in other tuberous taxa such as Dicentra canadensis (Lin et al., 2016) and Crocus sativus (Negb et al., 1989).

The much greater number of leaves in Patch IV and the greatest length of leaves in Patches III and IV might increase the effectiveness of light capture during photosynthesis in the neighbourhood of plants with considerable dimensions. The lack of temporal variability and significant spatial variability of Gladiolus imbricatus leaf blade dimensions was already observed by Kostrakiewicz-Gierałt (2014b). The aforementioned author found that the rise of the dimensions of leaf blades of Gladiolus imbricatus was observed in populations inhibiting Molinion meadows in the course of succession. The observed increase of leaf blade dimensions might be result of augmentation of soil humidity. Similar scenario was noticed in Gladiolus grandiflorus (Pereira et al., 2016a). On the other hand, the findings of Kubikova and Zeidler (2011) did not show either temporal or spatial variability.

The lack of temporal and considerable spatial variability of dimensions of generative shoots, inflorescences and flowers support previous outcomes (Kostrakiewicz-Gierałt, 2014b). The significant augmentation of dimensions of generative shoots might be result of growing ground moisture. The positive relationship among soil humidity and number and dimensions of shoots, flowers and inflorescences was observed in Gladiolus grandiflorus (Porto et al. 2014; Pereira et al. 2016a, 2016b). The reducing flowering of Gladiolus individuals in effect of decrease of soil moisture was also observed by Shillo and Halevy (1976). The occurrence of the highest generative shoots of Gladiolus imbricatus, as well as the longest inflorescences and flowers in the vicinity of tall-growing neighbours might improve the flower visibility for pollinators from the order Hymenoptera, which are attracted particularly by blue, pink, purple and mauve colours (Kevan \& Baker, 1983; Menzel \& Shmida, 1993; Miller et al., 2011). The number of seed capsules growing in subsequent study sites seems to confirm the successful pollination.

At the same time, it should be pointed out that the increase in the dimensions of generative shoots of Gladiolus imbricatus in the vicinity of tall-growing species enables the location of seed capsules in higher layers of the plant cover. The position of the fruits seems to be one of the 
decisive factors in the enhancement of wind disseminated propagules in new sites. Such a phenomenon was previously observed in several anemochorous species such as Serratula tinctoria (Bischoff, 2002; Bischoff et al., 2009).

\section{Conclusions}

In light of the performed investigations it can be concluded that the population occurring in Patch I (abandoned moorgrass meadow) presents the best condition despite the lowest abundance of shoots. The occurrence of juvenile, vegetative and generative shoots in Patch I might suggest the successful seedling recruitment. Moreover, the other more abundant populations (Patches II-IV) might persist in the colonized sites thanks to the vegetative multiplication of ramets and maximisation of chances for successful pollination and effective seed dispersal.

\section{Acknowledgements}

I would like to express my gratitude for two anonymous Reviewers for valuable comments and remarks, which enabled the great improving of previous version of manuscript.

\section{References}

Ali A., Mehmood T., Hussain R., Bashir A., Najam S. \& Ahmad A., 2014, Investigation of bio fertilizers influence on vegetative growth, flower quality, bulb yield and nutrient uptake in Gladiolus (Gladiolus grandiflorus L.), International Journal of Plant, Animal and Environmental Sciences 4(1): 94-99.

Andrušaitis G., 2003, Red Data Book of Latvia, Vol. 3. Vascular Plants, Institute of Biology, Riga.

Babczyńska-Sendek B., Błońska A., Bula R., Cabała S., Hejduk-Michalska D., Hereźniak J., Kołodziejek J., Krajewski Ł, Krause R., Mitka J., Nowak T., Parusel J.B., Piwowarczyk R., Posz E., Siciński J.T., Spałek K., Szendera W., Urbisz A., Urbisz A., Węgrzynek B., Wika S., Wilczek Z. \& Zalewska-Gałosz J., 2012, Czerwona lista roślin naczyniowych województwa śląskiego [The red list of vascular plants of Silesian Voivodship], [in:] Czerwone listy wybranych grup grzybów i roślin województwa śląskiego [The red lists of chosen groups of mushrooms and plants of Silesian Voivodship], J.B. Parusel, A. Urbisz (ed.), Centrum Dziedzictwa Przyrody Górnego Śląska, Katowice, Poland: 105-182.

Bischoff A., 2002, Dispersal and establishment of floodplain grassland species as limiting factors in restoration, Biological Conserv. 104: 25-33.
Bischoff A., Warthemann G. \& Klotz S., 2009, Succession of floodplain grasslands following reduction in land use intensity: the importance of environmental conditions, management and dispersal, Journal of Applied Ecology 46: 241-249.

Bróż E. \& Przemyski A., 2009, The red list of vascular plants in the Wyżyna Małopolska Upland (S Poland), [in:] Rare, relict and endangered plants and fungi in Poland, Z. Mirek \& A. Nikel (ed.), W. Szafer Institute of Botany, Polish Academy of Sciences, Kraków: 123136.

Cantor M. \& Tolety J., 2011, Gladiolus, [in:] Wild Crop Relatives: Genomic and Breeding Resources: Plantation and Breeding Recources, Plantation and Ornamental Crops, Ch. Kole (ed.), Springer-Verlag Berlin Heidelberg: 133-156.

Clothier T., 2003, Seed Germination Database, http://tomclothier.hort.net/page03.html.

Cwener A., Michalczuk W. \& Krawczyk R., 2016, Red list of vascular plants in the Lublin region, Annales UMCS, sectio C, Biologia 71(1): 8-26.

Dubiel E., 1991, Mapa roślinności rzeczywistej miasta Krakowa [Map of actual vegetation of the city of Cracow], Zeszyty Nauk UJ, Prace Botaniczne 22: 121-133.

Dubiel E., 1996, Łąki Krakowa. Część I: Klasa MolinioArrhenatheretea [Meadows in Cracow. I. MolinioArrhenatheretea class], Studia Ośrodka Dokumentacji Fizjograficznej PAN 24: 145-171.

Falkowski M., 2002, Nowe stanowisko Gladiolus imbricatus (Iridaceae) w dolinie środkowej Wisły [A new locality of Gladiolus imbricatus (Iridaceae) in the middle Vistula River valley], Fragmenta Floristica et Geobotanica 9: 369-370.

Głowacki Z., Falkowski M., Krechowski J., Marciniuk J., Marciniuk P., Nowicka-Falkowska K. \& Wierzba M., 2003, Czerwona lista roślin naczyniowych Niziny Południowopodlaskiej [The red list of vascular plant of the Południowopodlaska Lowland], Chrońmy Przyrodę Ojczystą 59: 5-41.

Gorzelak P., 2012, Nowe stanowisko mieczyka dachówkowatego Gladiolus imbricatus L. (Iridaceae) na Dolnym Śląsku [New locality of Gladiolus imbricatus L. (Iridaceae) in Lower Silesia], Acta Botanica Silesiaca 8: 147-154.

Holub J. \& Proházka F., 2000, Red List of vascular plants of the Czech Republic, Preslia 72: 167-186.

Hultén E. \& Fries M., 1986, Atlas of North European vascular plants. North of the Tropic of Cancer. I-III, Koeltz Scientific Books, Königstein, Germany.

Jackowiak B., Celka Z., Chmiel J., Latowski K. \& Żukowski W., 2007, Red list of vascular flora in Wielkopolska (Poland), Biodiversity: Research and Conservation 5-8: 95-127. 
Jakubowska-Gabara J. \& Kucharski L., 1999, Ginące i zagrożone gatunki flory naczyniowej zbiorowisk naturalnych i półnaturalnych Polski Środkowej [Endangered and threatened vascular plants in natural and seminatural communities in Central Poland], Fragmenta Floristica et Geobotanica, series Polonica, 6: 55-74.

Jõgar Ü. \& Moora M., 2008, Reintroduction of a rare plant (Gladiolus imbricatus) population to a river floodplain - How important is meadow management?, Restoration Ecology 16: 382-385.

Kaźmierczakowa R., Bloch-Orłowska J., Celka Z., Cwener A., Dajdok Z., Michalska-Hejduk D., Pawlikowski P., Szczęśniak E. \& Ziarnek K., 2016, Polska czerwona lista paprotników i roślin kwiatowych [Polish red list of pteridophytes and flowering plants], Instytut Ochrony Przyrody Polskiej Akademii Nauk, Kraków.

Kevan P.G. \& Baker H.G., 1983, Insects as flower visitors and pollinators, Annual Review of Entomology 28: 407-53.

Khattab M., Raslan M., Nabih A. \& Selim A. 2016, Effect of some fertilizer treatments on the growth of cormels of Gladiolus and corms production, Alexandria Science Exchange Journal 37(4): 561-571.

Király G., ed., 2007, Vörös Lista [Red List of the Vascular flora in Hungary], Saját kiadás, Sopron, Hungary.

Klimešová J. \& Klimeš L., 2006, Clo-Pla3 - Database of clonal growth of plants from Central Europe. [http:// clopla.butbn.cas.cz/].

Kołodziejek J., 2011, Gladiolus imbricatus L. mieczyk dachówkowaty [Gladiolus imbricatus L. Turkish Marsh Gladiolus, [in:] Czerwona Księga Roślin Województwa Łódzkiego [Red list of vascular plants of Łódź voivodship], R. Olaczek (ed.), Ogród Botaniczny w Łodzi, Uniwersytet Łódzki, Łódź: 100-101.

Kołos A., 2015, Nowe stanowisko Gladiolus imbricatus (Iridaceae) na Nizinie Północnopodlaskiej [A new locality of Gladiolus imbricatus (Iridaceae) in the North Podlasie Lowland], Fragmenta Floristica et Geobotanica 22(2): 390-395.

Kose M. \& Moora M., 2005, Monitoring the wild gladiolus (Gladiolus imbricatus) population under different meadow management regimes, [in:] Coastal meadow management: best practice guidelines, R. Rannap, L. Briggs, K. Lotman, I. Lepik, I. \& V. Rannap (eds), Ministry of the Environment of the Republic of Estonia, Tallinn: 70-71.

Kostrakiewicz-Gierałt K., 2014a, The effect of neighbouring plant height, disturbance level and gap size on spontaneous recruitment of large-seeded and smallseeded species in Molinietum caeruleae meadows, Polish Journal of Ecology 62: 289-306.

Kostrakiewicz-Gierałt K., 2014b, The variability of selected features of Gladiolus imbricatus L. in relation to successive stages of meadow communities follow- ing the mowing cessation, Polish Journal of Ecology 62: 307-321

Kubikova P. \& Zeidler M., 2011, Habitat demands and population characteristics of the rare plant species Gladiolus imbricatus L. in the Frenštát region (NE Moravia, the Czech Republic), Časopis Slezského zemského muzea, Série A, Vědy př́rodní 60: 154-164.

Lilleleht V. 1998, The red data book of Estonia. Threatened plants, fungi and animals ETA, Looduskaitse Komisjon, Tartu, Estonia.

Lin C-H, Miriti M.N. \& Goodell K., 2016, Demographic consequences of greater clonal than sexual reproduction in Dicentra Canadensis, Ecology and Evolution 6(12): 3871-3883.

Markowski R. \& Buliński M., 2004, Ginące i zagrożone rośliny naczyniowe Pomorza Gdańskiego [Endangered and threatened vascular plants of Gdańskie Pomerania], Acta Botanica Cassubica, Monographiae 1: 1-75.

Memon N., Qasim M., Jaskani M.J., Ahmad R. \& Ahmad H., 2009, Enhancement of corm and cormel production in gladiolus (Gladiolus spp.), New Zealand Journal of Crop and Horticultural Science 37(4): 319-325.

Menzel, R. \& Shmida A., 1993, The ecology of flower colors and the natural color vision of insect pollinators: the Israeli flora as a study case, Biological Review 68: 81-120.

Miller R., Owens S.J. \& Rorslett B., 2011, Plants and colour: flowers and pollination, Optics and Laser Technology 43: 282-294.

Mirek Z., Nikel A. \& Wilk Ł., 2014, Najbogatsze w Tatrzańskim Parku Narodowym stanowisko Gladiolus imbricatus (Iridaceae) [The most abundant population of Gladiolus imbricatus (Iridaceae) in the Tatra National Park], Fragmenta Floristica et Geobotanica Polonica 21(2): 392-395.

Moora M., Kose M. \& Jogar U., 2007, Optimal management of the rare Gladiolus imbricatus in Estonian coastal meadows indicated by its population structure, Applied Vegetation Science 10: 161-168.

Moser D., Gygax A., Baumler B., Wyler N. \& Palese R., 2002, Liste Rouge des fougères et plantes à fleurs menaces de Suisse, Office federal de l'environnement, des forêts et du paysage, Berne, Switzerland.

Mróz L., 2006, Variation in stage structure and fitness traits between road verge and meadow populations of Colchicum autumnale (Liliaceae): Effects of habitat quality, Acta Societatis Botanicorum Poloniae 75(1): 69-78.

Negb M., Dagan B., Dror A. \& Basker D., 1989, Growth, flowering, vegetative reproduction, and dormancy in the saffron crocus (Crocus sativus L), Israel Journal of Botany 38(2-3): 95-113.

Pereira M.T.J., da Silva T.J. \& Bonfim Silva E.M., 2016a, Soil water content and wood ash fertilization on the 
cultivation of gladiolus, Revista Brasileira De Engenharia Agricola E Ambiental 20(4): 350-356.

Pereira M.T.J., da Silva T.J., Bonfim Silva E.M. \& Mazzini R.B.M., 2016b, Applying wood ash and soil moisture on gladiolus (Gladiolus grandiflorus) cultivation, Australian Journal of Crop Science 10(3): 393-401.

Porto R.D., Koetz M., Bonfim-Silva E.M., Polizel A.C. $\&$ da Silva T.J.A., 2014, Effects of water replacement levels and nitrogen fertilization on growth and production of gladiolus in a greenhouse, Agricultural Water Management 131: 50-56.

Piórek K. \& Krechowski J., 2009, Bogate stanowisko mieczyka dachówkowatego Gladiolus imbricatus L. na terenie Nadbużańskiego Parku Krajobrazowego (Nizina Południowopodlaska) [Rich stand of Gladiolus imbricatus L. in the Nadbużański Landscape Park (Nizina Południowopodlaska Lowland)], Chrońmy Przyrodę Ojczystą 65 (3): 201-204.

Rakosy-Tican E., Bors B. \& Szatmari A-M., 2012, In vitro culture and medium-term conservation of the rare wild species Gladiolus imbricatus, African Journal of Biotechnology 11(81): 14703-14712.

Rameau C. \& GouyonP.-H., 1991, Resource allocation to growth, reproduction and survival in Gladiolus: the cost of male function, Journal of Evolutionary Eco$\operatorname{logy}$ 4: 291-307.

Reintal M., Tali K., Haldna M. \& Kull T., 2010, Habitat preferences as related to the prolonged dormancy of perennial herbs and ferns, Plant Ecology 210: 111-123.

Rombel-Bryzek A., 2007, Stanowisko mieczyka dachówkowatego Gladiolus imbricatus L. w Parku Krajobrazowym Chełmy na Pogórzu Kaczawskim [The locality of Gladiolus imbricatus L. in Landscape Park Chełmy on the Pogórze Kaczawskie Foothills], Chrońmy Przyrodę Ojczystą 63(1): 101-105.

Rozporządzenie Ministra Środowiska z dnia 9 października 2014 r. o ochronie gatunkowej roślin (Dz.U. RP 2014, poz. 1409, Kanc. Prezesa Rady Min.) [Regulation of the Minister of the Environment of 9 October 2014 on the species-specific protection of plants (Journal of Laws RP 2014, item 1409, Chancellery of the Prime Minister)], 2014, Warszawa.

Saeed R.M., Bazaraa W. M. \& Nabih A., 2014, Effect of growing media, organic fertilization and biostimulants on the production of Gladiolus (cv. Novalux) corms from cormlets, Scientific Journal of Flowers and Ornamental Plants (1): 73-87.

Shillo R. \& Halevy A.H., 1976, The effect of various environmental factors on flowering of gladiolus. III. Temperature and moisture, Scientia Horticulturae 4(2): $147-155$.

Szczepaniak M., Kamiński R., Kuta E., Słomka A., Heise W. \& Cieślak E., 2016, Natural hybridization between Gladiolus palustris and G. imbricatus inferred from morphological, molecular and reproductive evidence, Preslia 88(1): 137-161.

Tałałaj I., 2015, Biologia i ekologia wybranych gatunków storczyków naziemnych, [w:] Różnorodność biologiczna - od komórki do ekosystemu. Funkcjonowanie roślin i grzybów. Środowisko - eksperyment - edukacja [Biology and ecology of selected species of terrestrial orchids, [in:] Biodiversity - from cell to ecosystem. Functioning of plants and fungi. Environment experiment - education], A. Bajguz., I. Ciereszko (eds), Polskie Towarzystwo Botaniczne, Białystok: 103-115.

Zając A. \& Zając M. (eds), 2001, Atlas rozmieszczenia roślin naczyniowych w Polsce [Distribution Atlas of Vascular Plants in Poland], Pracownia Chorologii Komputerowej Instytutu Botaniki UJ, Kraków.

Zarzycki K., 1958, Wilgotne łąki w okolicach Czernichowa i potrzeba ich ochrony [Humid meadows in the environs of Czernichów near Cracow deserving protection], Ochrona Przyrody 25: 49-68.

Ziaja M. \& Wójcik T., 2016, Występowanie Gladiolus imbricatus (Iridaceae) w zbiorowiskach łąkowych w obszarze Natura 2000 Ląki w Komborni (PLH180042, SE Poland) [The occurrence of Gladiolus imbricatus (Iridaceae) in meadow communities of the Łąki w Komborni Natura 2000 site (PLH180042, SE Poland], Fragmenta Floristica et Geobotanica 23(2): 219-230. 